\title{
SOME ASPECTS OF UNDERSTANDING THE CATEGORY OF "PEACEFULNESS" IN THE PRACTICE OF THE EUROPEAN COURT OF HUMAN RIGHTS AS A CONDITION FOR RESPECT FOR THE RIGHT TO FREEDOM OF PEACEFUL ASSEMBLY
}

The paper is devoted to the analysis of national and international conditions for the exercise of the right to freedom of peaceful assembly, among which the category of "peacefulness" occupies a prominent place. The Convention for the Protection of Human Rights and Fundamental Freedoms, as well as the Constitution of Ukraine, unanimously state that citizens have the right to assemble only peacefully. This formulation defines the purpose of the article, to achieve which the author considers in more detail the content of the category of "peacefulness", which is a prerequisite for the exercise of the right to freedom of peaceful assembly. To achieve the stated purpose, the author uses the methods and techniques of logic, from general to specific, namely analyzes the practice of the European Court of Human Rights in the cases of the exercise of the right of citizens to freedom of peaceful assembly, which results in the development of criteria for determining the peaceful character of the assembly. The author dwells on such aspects of the category of "peacefulness" as: the absence during the assembly or non-use of weapons by its participants; lack of purpose and desire to use violence in the organizers and participants of the assembly; active non-peaceful actions of counter demonstrators of the peaceful assembly; appeals and slogans of the assembly, including of the national or political nature, which cause dissatisfaction with the rest of the population; peculiarities of evaluation of negative actions of individual participants in public assemblies.

As the conclusion, the author notes that the absence in the Ukrainian legislation of a special law that would regulate the procedural aspects of the exercise by citizens of the right to freedom of assembly leads to the creation of situations that result in numerous violations, including in the form of an unjustified ban on the right of citizens to exercise their rights.

On grounds of this state of affairs, the author sees fit to actively use sources of international law, which have important developments in the regulation of this sphere. One of the most significant sources is the practice of the European Court of Human Rights as an integral part of the Convention for the Protection of Human Rights and Fundamental Freedoms, which provides, among other things, a substantial interpretation of the category of "peacefulness" in the resolution of disputes related to violation of the right to freedom of peaceful assembly. The developments of the European Court of Justice should not only be a definite benchmark for the organizers and participants in the peaceful assembly, but also be fully applied by the subjects of public administration.

Key words: peaceful character, non-violent character, weapons, counter demonstrators, slogans, posters, public assemblies, public place. 


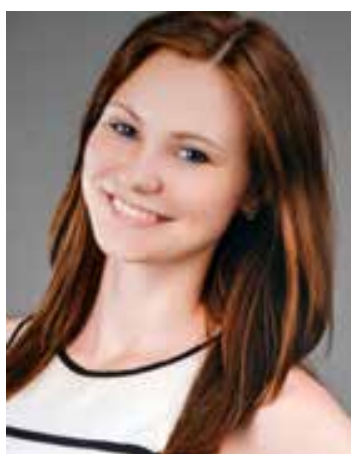

Kateryna Solodova, PhD-Student, Researcher, Georg-August-University Goettingen orcid.org/0000-0001-9878-2802 solodova_kateryna@ukr.net

\section{Introduction}

It is extremely important for Ukraine, like any other democratic state, to ensure and adhere to international standards and principles in the field of human rights. One of the most important acts aimed at establishing and guaranteeing the latter is the European Convention on Human Rights (hereinafter referred to as the Convention), an integral part of which is the judgment of the European Court of Human Rights (ECHR). In addition, it should be noted that at the level of law, the ECHR judgment has been recognized in Ukraine as a source of law, and therefore their application, including of the subjects of public administration, is mandatory (Verkhovna Rada of Ukraine, 2006).

The right to freedom of peaceful assembly occupies a pride of place in the Convention (Article 11) (Verkhovna Rada of Ukraine, 1997) and the Constitution of Ukraine (Article 39) (Verkhovna Rada of Ukraine, 2016). Although the right to freedom of peaceful assembly is enshrined at the level of the highest sources of law, this sphere of legal relations has not yet found its proper legal regulation in Ukraine. The absence of a special law that would regulate the procedural aspects of the exercise by citizens of the right to freedom of assembly leads to the creation of situations that result in numerous violations, including in the form of an unjustified ban on the right of citizens to exercise their rights. A similar position of the ECHR was expressed in "Verentsov v. Ukraine", noting that, in the absence of any clear and foreseeable legislative provisions on the regulation of the organization and conduct of demonstrations, the conviction of a person for violation of a non-existent procedure is incompatible with Article 7 of the Convention (no punishment without law) and Article 11 of the Convention (freedom of assembly and association), while the violation of these articles in Ukraine is due to the legislative gap in the freedom of assembly that has remained in the Ukrainian legal system for more than two decades (European Court of Human Rights, 2013).

Cases on the establishment of restrictions on the exercise of the right to freedom of peaceful assembly (assemblies, rallies, campaigns, demonstrations, etc.) are considered by administrative courts (Code of Administrative Justice of Ukraine: Law of Ukraine (Verkhovna Rada of Ukraine, 2005)). It is also interesting that the administrative courts themselves point out the problem of the lack of proper legislative regulation in their judgments'. Thus, in the judgment of the Babushkinsky District Court of Dnipropetrovsk on March 30, 2007, in the case 
of S. v. the Executive Committee of the Dnipropetrovsk City Council concerning the adoption of regulations on holding mass events in the city of Dnipropetrovsk, the court held, inter alia, that the procedures for exercising the right to freedom of assembly and the procedures and grounds for restricting the right were not regulated by Ukrainian legislation and therefore the Council had no grounds for adopting the impugned regulation, which would interfere with the rights of citizens. In the absence of proper legal regulation, administrative courts have a wide scope to motivate negative judgments' for citizens. Due to this state of affairs, we see fit to actively use sources of international law, which have important developments in the regulation of this sphere. One of the most significant sources is the practice of the European Court of Human Rights.

The analysis of the right to freedom of peaceful assembly, including in the context of European practice, was the subject of the study of such scientists as R. Kuibida (Kuibida et al., 2018), R. Melnik (Melnyk, 2015), O. Shkarneha (Shkarneha, 2016) and others.

\section{Current state of source base}

The main legislative sources (the above provisions of Article 11 of the Convention and Article 39 of the Constitution of Ukraine) and the European Court of Human Rights unanimously state that citizens have the right to assemble only peacefully, which makes us consider in more detail the content of the category of "peacefulness", which, accordingly, is a prerequisite for the exercise of the right to freedom of peaceful assembly. In one of the judgments, the Constitutional Court of Ukraine, when considering the issue of whether the Constitution of Ukraine complies with the provisions of part five of Article 21 of the Law of Ukraine "On Freedom of Conscience and Religious Organizations", the latter only briefly referred to the category of "peacefulness", citing, as an example, the Guidelines on Freedom Peaceful Assembly (2nd edition) prepared by the Organization for Security and Co-operation in Europe / the Office for Democratic Institutions and Human Rights and the European Commission for Democracy through Law (Venice Commission) (Constitutional Court of Ukraine, 2016). Thus, the Constitutional Court of Ukraine shares the opinion of international organizations that an assembly is considered to be peaceful if has a non-violent nature and its organizers have peaceful intentions. Western scholars point out that the requirement of the assembly's peacefulness is closely linked to the understanding of freedom of assembly as an instrument of participation in the (political) decision-making process in a democratic society, in which violence can in no way be a means of achieving purposes (Dörr et al., 2013: 1169-1170). However, both the Convention and the Constitution of Ukraine protect not only the right of people to assemble peacefully, but also provide for a mandatory condition for the exercise of this right, according to which participants of the assembly should be without weapons.

3. The concept of "weapons" in the context of the right to freedom of peaceful assembly

Definition of the concept of "weapons" in modern national legislation can be found in the Instruction on the use of weapons, military equipment, hardware, ships (boats), planes and helicopters of the State Border Guard Service of Ukraine, special means and measures of physical influence during the protection of the state border and the exclusive (sea) economic zone of Ukraine, approved by the order of the Administration of the State Border Guard Service of Ukraine dated October 21, 2003 № 200 (State Border Guard 
Service of Ukraine, 2003). Thus, in accordance with paragraph 1.3 of the Instruction, weapons are objects and devices intended for the destruction of living targets, ships, aircraft (helicopters) and other objects and have no other purpose. In turn, scholars in different ways approach definition of the concept of "weapons", basing their thoughts on the principle of integrated industry of this concept. Thus, some state that in the administrative law weapons are part of the permit system, an object, usage of which requires obtaining prior permission from a competent executive body of State authority, that is, the circulation of which is carried out in a permissive manner, while in the constitutional law weapons are a means of satisfaction of the constitutional rights of citizens to self-defense (Pietkov, 2008: 17-18]. In more detail, the concept of "weapons" in the sense of Article 39 of the Constitution of Ukraine R. Melnyk concludes that in this context the weapon is: firearm of any kind (military, hunting, etc.); devices for shooting cartridges equipped with rubber or similar in their properties non-lethal projectiles; pneumatic weapons; cold weapons; cold missile weapons; items specially adapted or prepared in advance for bodily injuries; explosives and explosive devices (Melnyk, 2015: 103-104). Summarizing these definitions, we formulate our own opinion, defining weapons in the context of the exercise of the right to freedom of peaceful assembly as weapons in its technical sense, as well as those items that by their nature can be used to cause damage to the life and health of a person or his property.

The requirement of peacefulness from the outset implies that non-peaceful assemblies, and therefore armed assemblies, are automatically excluded from the application of Article 11 of the Convention. Debatable, however, remains the issue of whether participants of the assembly who have the legal right to carry weapons can attend the assembly. On the one hand, the presence of weapons among the participants in the assembly may be considered as a ground for violation of the peacefulness - a key condition for the exercise of this right. However, if Article 11 of the Convention is to be more widely considered, it is quite possible to assume that the assembly will have a peaceful nature, even if its participants have weapons, but do not intend to apply it. This is especially true in those situations where the participants and organizers of the assembly are those who already have weapons as an integral part of their profession. Such categories of individuals are police officers or hunters.

\section{Non-violent character of the assembly}

Another aspect of the category of "peacefulness" lies in a more hidden form of the threat of violations of peacefulness than weapons. These are the cases where the organizer or some participants of the assembly intend to use violence, approve such behavior from other individuals or have another kind of danger that manifests itself in the application of aggressive actions against people or their property. The ECHR directly denies the peaceful character of the assembly if its organizers from the outset have intentions to accomplish their violent purposes (European Court of Human Rights, 2001). Similar actions of the participants of the peaceful assembly, of course, result in at least a violation of public order (in this case, it is worth noting that the category of "public order" in the Ukrainian legislation is uncertain, and therefore in practice it leads to significant problems), however, the prohibition of holding an assembly is not justified only by the fact that the participants of the assembly violate the latter. For example, the ECHR suggested 
that the assembly was peaceful in the case when a group of foreigners without valid residence permits decided to take collective action to draw the attention of the community to the difficulties they had in obtaining a revision of their immigration status in France. Their campaign ended with the decision to occupy the church of St. Bernard, where the group has lived for about two months. Neither the priest nor the parish council of the church were against their presence, and religious services and various ceremonies were held as planned without incidents (European Court of Human Rights, 2002). In addition, cases such as aggressive slogans ("Off...") in conjunction with the arson of flags or portraits, also in the opinion of the ECHR, in themselves, do not indicate the non-peaceful character of the assembly (European Court of Human Rights, 2010a). The court finds it difficult to imagine a huge political demonstration during which people will be able to express their opinions without resorting to a certain noise (European Court of Human Rights, 2007a). The ECHR notes that such actions should be understood as expressions of dissatisfaction and protest, but they can hardly be considered a call to violence, even if they are accompanied by the arson of flags and photographs of political figures. The ECHR considers such actions to be a form of expression of opinion on a matter of great public interest and reminds that members of the assembly have the right to freedom of expression concerning not only information or ideas that are positively perceived in society, but also those who offend, shock or hinder certain individuals (European Court of Human Rights, 1994: 94). This opinion is confirmed by the ECHR in another judgment, stating that Article 11 of the Convention protects a meeting that may annoy or cause negative emotions in other individuals who oppose the ideas or claims that such a peaceful assembly seeks to achieve (European Court of Human Rights, 1988: 88).

\section{Assessment of the actions of counter-demonstrators of the peaceful assembly as an opportunity to ban it}

Along with this, one can also recall the position of the ECHR, set out in the case of Schwabe v. Germany, which discussed the prohibition of holding a peaceful assembly for participants who intended to participate in demonstrations against the G8 summit. The ECHR noted that the applicants did not expose violent intentions: no weapons were found, and the formulation of the inscriptions on the banners did not allow to prove that the participants intended to incite others to violence. But the possibility of violent counter-demonstrations or the possibility of adding to the demonstration of extremists with violent intentions can not, as such, take away the right to freedom of peaceful assemblies. The notion of "peaceful assembly" does not cover those cases where organizers and participants have violent intentions that from the very beginning lead to mass disturbances (European Court of Human Rights, 1980a).

Continuing to analyze the practice of the ECHR, we see that any counter-demonstrations or disturbances provoked by the assembly can neither lead to the automatic absence of a peaceful character of the assembly nor serve as grounds for its prohibition or dissolution. A similar statement applies even when the purpose of the assembly is controversial, and counter-demonstrations should be feared. This position was expressed in more detail by the ECHR in the judgment of Alekseyev v. Russia, which stressed that if each probability of tension and incitement of confrontation between the opposing groups during the assembly would justify its prohibition, society would face the loss 
of the opportunity to hear different views on any issue that offends the feeling of the majority (European Court of Human Rights, 2010b). In this case, the rights of minorities to freedom of expression and peaceful assembly would become only theoretical, not practical and effective, as required by the Convention (European Court of Human Rights, 1980b). In this regard, the ECHR insists that Article 11 of the Convention, on the contrary, implies the duty of the state to protect members of the peaceful assembly from unfriendly opponents of the demonstration (European Court of Human Rights, 1988). Taking into account the above, the ECHR also explicitly states that the burden of proving violent intentions of the organizers of the assembly lies with the authorities and it can not avoid it by imposing on organizers, for example, the exclusion of the participation of certain groups of individuals, or asserting special claims on the organizers of the assembly (European Court of Human Rights, 2010a). Moreover, the ECHR also points out that state authority should not only protect the right to assemble peacefully, but should also refrain from unreasonable indirect restrictions on this right (European Court of Human Rights, 2006a). Continuing this idea, the ECHR adds that although the main object of Article 11 is the protection of a citizen from arbitrary interference of the authorities in the process of the enforcement of guaranteed rights, obligations for the effective exercise of these rights must also be adhered to (European Court of Human Rights, 2003). The ECHR believes that these principles are also applicable to the issue of demonstrations and rallies organized in public places (European Court of Human Rights, 2006a). This position was substantiated by the ECHR in detail in the judgment of the Makhmudov v. Russia, where the applicant complained about the prohibition of holding a peaceful assembly (European Court of Human Rights, 2007b). The reason for the prohibition was the announcement of a terrorist act. In accordance with the circumstances of the case, law enforcement agencies were informed about a possible terrorist act, after which the authorized body decided to revoke the previously issued permission to hold a peaceful assembly. During the trial, the national courts found that the district police did not confirm the fact of the terrorist report, and the regional police refused to provide information, referring to secrecy considerations. In these circumstances, the ECHR concluded that since the authorities relied on information about a "terrorist threat" as grounds for prohibiting the assembly, they were based on assumptions rather than on real facts. Moreover, considering the circumstances of the case as a whole, the ECHR sees compelling reasons to doubt the Statement of the respondent State that the potential threat of a terrorist attack was the real reason for the applicant's refusal to issue a permit for an assembly. In substantiating its position on this case, the ECHR emphasizes that if the relevant authorities were notified of possible terrorist attacks in places of mass gathering, such information, being rather serious and trustworthy, should have led to an increase in security measures in public places, theaters, exhibition halls, sports grounds, etc., and the fact that disturbing information was received before the celebration of the City Day could actually result in the abolition of a number of measures to ensure the safety of the participants. However, as can be seen from the media reports submitted by the plaintiff and not protested by the state, the events organized by the city hall and the government were held in accordance with the approved program on the day following the day of the scheduled assembly. Although the number of those present at the events significantly 
exceeded the number of expected participants in the assembly of the applicant, the latter was the only event that was canceled due to the terrorism threat. In this regard, the ECHR considers that the threat of violations of the peacefulness of the assembly has not been proved, and thus the abolition of the permit for its holding violates Article 11 of the Convention. It is clear that in each particular case the court must independently determine the degree of risk of creating a real danger of disturbances or crimes, threats to public health or the rights and freedoms of other people, a real possibility for executive authorities and local self-government to fulfill their authority to ensure the protection of public order during peaceful assemblies, assess the real danger of holding an assembly for the national-security and public-order interests. However, as shown by the practice of the national administrative courts, by satisfying claims about the prohibition of a peaceful assembly or by imposing other restrictions on the exercise of the right to peaceful assembly, courts often saw the possibility of violating national-security and public-order interests in preventing the free access of citizens and employees to state institutions, next to with events were planned; violation of the normal traffic of vehicles in the areas of roads close to the venue; the possibility of conflict situations in case of coincidence in place and time of several peaceful assemblies of different (often opposite) ideological directions, etc. (Supreme Administrative Court of Ukraine, 2012). The practice of the ECHR shows that not always the application of radical measures in the form of depriving citizens of the right to exercise the right to freedom of assembly is justified and necessary in a democratic society.

6. The purpose and location of holding the assembly as a criterion for determining its "peacefulness"

It is not uncommon for authorities to illegally deprive citizens of the possibility of exercising the right to freedom of assembly by prohibiting its holding and justifying this as a threat to the functioning of state power or the interference with the work of its bodies. However, the ECHR, when formulating its own opinion on this matter, in particular, in the case of Kuznetsov v. Russian Federation, noted that even such actions as blocking access to a court building during a picket are not a violation that allows the authorities to apply a prohibition or other action, adding that any demonstration in a public place inevitably introduces certain changes in normal life, including road traffic offenses, so it is especially important for public authorities to demonstrate a certain level of tolerance in relation to peaceful assemblies (European Court of Human Rights, 2008).

Further the ECHR indicates that the assembly does not always lose its character of peacefulness even if its members insist on fundamental constitutional changes and, for example, seek greater autonomy or even separation from the state (European Court of Human Rights, 2001), have a potential impact on national interests, public order, or territorial integrity, contain the words "resistance", "fight" and "liberation". In the context of the possibility of violating the peacefulness of the assembly, the ECHR notes that the above actions do not lead to a clear conclusion that the participants of such an assembly call for violence, armed resistance or rebellion (European Court of Human Rights, 2001). At the same time, the ECHR emphasizes that one of the key characteristics of democracy is the ability to solve the problems of the state through dialogue, without resorting to violence, even if these problems are irritating to certain categories of people or authorities. 
Democracy flourishes with freedom of expression. From this point of view, there is no justification for blocking a group of people simply because it seeks to debate on the situation of parts of the population, and tries to find a solution according to democratic rules, able to satisfy all interests (European Court of Human Rights, 1998a). Continuing this idea, in another judgment, the ECHR noted that only very serious violations that threaten political pluralism or fundamental democratic principles could justify the prohibition of an assembly. If, during the assembly there are no calls for violent overthrow of power or any other actions that undermine the principles of pluralism and democracy, it is unwise to assert that the prohibition of an assembly is proportional to its persecuted purpose and that it meets the "pressing social need" (European Court of Human Rights, 2006b).

In this context, the ECHR has indicated that in cases of incitement to violence against a public official or group of officials, public authorities generally have greater freedom of discretion, considering the need for interference with the freedom of expression, but automatically in this case the character of the peaceful assembly is not violated (European Court of Human Rights, 1998b; European Court of Human Rights, 1999).

7. Distinctions of estimation of the actions of individual participants in the assembly

A particular problem, mainly in large events, is how to estimate the violence of individual participants or groups. Obviously, the possibility of disturbances, violence or other unsatisfactory behavior can never be ruled out. They can even be predictable, considering only the very topic of the assembly. However, if one was enough to prohibit the assembly in advance or to dismiss the assembly after its commencement, the protection of fundamental rights for a predominantly peaceful part of the assembly would be violated, since in this case the possibility of applying a fundamental right is in fact in the hands of individuals or groups of individuals. Accordingly, the ECHR considers that, where demonstrators are not involved in acts of violence, it is important that the authorities to some extent exercise tolerance towards peaceful assemblies of civilians, otherwise freedom of assembly guaranteed by Article 11 of the Convention will become devoid of purpose. In such cases, the police intervention or the intervention of another kind is disproportionate and is not necessary to prevent violations of public order (European Court of Human Rights, 2006a). Therefore, the non-peaceful conduct of individuals can not be considered a violation of the peaceful character of the assembly as a whole, even if prohibited acts occur from the participants of the event, and not counter-demonstrators. At the same time, if the degree of non-peaceful conduct reaches a certain threshold of harm, which must be determined in the light of the importance of the fundamental right, then this must and can be attributed to the assembly as a whole. In this case, the competent authorities of the state are obliged to determine the time from which the assembly itself went beyond the protection of fundamental rights as a result of the violation of the peacefulness of its holding. In this respect, the ECHR can only verify whether the estimation of the situation was conducted properly and in accordance with the fundamental right to freedom of assembly. This does not mean that the ECHR should restrict itself to establishing whether the respondent State exercises its discretion in a reasonable, cautious and fair manner; it must also consider the interference complained of, in the light of the case as a whole, and determine, after establishing that it 
pursues a "legitimate purpose", whether it is proportional to this purpose and whether the reasons given by the national authorities are justified and sufficient (European Court of Human Rights, 2001). Considering this, one can speak of the fact that the state's duty is to adhere to the declared right of citizens to hold a peaceful assembly. In particular, in the judgment of the Ouranio Toxo and others v. Greece, the ECHR indicated that the state police should reasonably foresee the danger that the tension in society on the port of the opponents of the participants in the peaceful assembly would turn into acts of violence and direct violations of the freedom of association of citizens (European Court of Human Rights, 2005). The State therefore had to take appropriate measures to prevent or at least to deter acts of violence. In cases where proper measures have not been taken by the state, the ECHR considers violations by public administration entities of internationally guaranteed rights. Thus, in another of its judgments', the ECHR points out that the authorities have resorted to a radical and unlawful means by refusing the citizen the fullest possible exercise of his right to freedom of peaceful assembly, and such a complete prohibion of holding a peaceful assembly can not be justified (European Court of Human Rights, 2007c). In the jundgement of the Djavit An v. Turkey (European Court of Human Rights, 2003) the ECHR also indicated that the probable danger of violations of the peacefulness of the assembly should not be conceivable. It should be based on concrete facts or data on the existence of a real threat to peace in society. The ECHR points out that any restriction on the right to freedom of peaceful assembly is possible only if real danger can be really seen. In addition, according to the ECHR, in order to ensure the normal holding of a peaceful assembly of citizens of a political, cultural or other character, it is important to take preventive security measures, such as the presence of first aid services in demonstration venues (European Court of Human Rights, 2006a).

\section{Conclusions}

On the basis of the foregoing, the following conclusions can be drawn: the European Court of Human Rights gives a meaningful interpretation of the category of "peacefulness" in resolving disputes related to violation of the right to freedom of peaceful assembly. In numerous judgments on the issue of the violation of Article 11 of the Convention for the Protection of Human Rights and Fundamental Freedoms, which guarantees the right to freedom of peaceful assembly, the European Court of Human Rights gives a detailed description of certain aspects of the category of "peacefulness", thus forming its contents. So, in the practice of the Court, we can find the following criteria for the category of "peacefulness":

the need for the absence of weapons or its legal presence in the participants of an assembly, but the lack of purpose of its application;

lack of purpose and desire to use violent intentions in the organizers and participants of an assembly;

the characteristics of the appeals and slogans of an assembly, including of the state or political nature;

the possibility of displaying active non-peaceful actions of counter demonstrators of a peaceful assembly or planned provocative conduct unsatisfied with the purpose of holding a peaceful assembly of a part of the population; distinctions of estimation of negative actions of individual participants in mass gatherings. 


\section{НАУКОВИЙ АНАЛІЗ СУДОВОЇ ПРАКТИКИ}

Certainly, these judgments' are worth the attention of the organizers and participants of peaceful assemblies. But moreover, taking into account the shortcomings of domestic legislation in regulating this issue, as well as the constitutional duty of public administration entities to apply the practice of the ECHR, the use of these judgments' will contribute to the democratic consolidation and the observance of human rights in Ukraine.

\section{Bibliography:}

1. Про виконання рішень та застосування практики Європейського суду з прав людини : Закон України від 23 лютого 2006 р. № 3477-IV / Верховна Рада України. Офіиійний вісник України. 2006. № 12. С. 16.

2. Про ратифікацію Конвенції про захист прав людини і основоположних свобод 1950 року, Першого протоколу та Протоколів № 2, 4, 7 та 11 до Конвенції : Закон України від 17 липня 1997 р. № 475/97-ВР / Верховна Рада України. Офіційний вісник Украӥни. 1997. № 29. С. 11.

3. Конституція України : Закон України від 28 червня 1996 р. № 254к/96-ВР (станом на 1 вересня 2016 р.). Відповідає офіційному тексту. Харків : Право, 2016. 82 с.

4. Справа «Веренцов проти України» : рішення Свропейського суду з прав людини від 11 квітня 2013 р. (заява № 20372/11). Офіційний переклад / Європейський суд з прав людини. URL: https://zakon.rada.gov.ua/laws/show/974_945.

5. Кодекс адміністративного судочинства України : Закон України від 6 липня 2005 p. № 2747-IV / Верховна Рада України. Офіџійний вісник України. 2005. № 32. С. 11.

6. Куйбіда Р., Середа М., Трубенкова О. Свобода мирних зібрань в Україні: пошук оптимальної моделі регулювання / Центр політико-правових реформ, Democracy Reporting International. 2018. 24 c. URL: http://pravo.org.ua/img/zstored/files/myrni_zibrannia_v_Ukraini.pdf.

7. Мельник Р. Право на свободу мирних зібрань: теорія і практика : монографія. Київ : BAITE, 2015. $168 \mathrm{c}$.

8. Шкарнега О. Провадження у справах щодо реалізації права на мирні зібрання : автореф. дис. ... канд. юрид. наук. Одеса, 2016. 13 с.

9. Рішення Конституційного Суду України у справі за конституційним поданням Уповноваженого Верховної Ради України з прав людини щодо відповідності Конституції України (конституційності) положень частини п’ятої статті 21 Закону України «Про свободу совісті та релігійні організації» (справа про завчасне сповіщення про проведення публічних богослужінь, релігійних обрядів, церемоній та процесій) від 8 вересня 2016 р. № 6-рп/2016 / Конституційний Суд України. Офіційний вісник України. 2016. № 79. С. 94.

10. Dörr O., Grote R., Marauhn T. EMRK/GG: Konkordanzkommentar zum europäischen und deutschen Grundrechtsschutz. 2. Auflage. Band 1. Kapitel 1-19. Tübingen, 2013. 1232 S.

11. Про затвердження Інструкції про застосування зброї, бойової техніки, озброєння, кораблів (катерів), літаків і вертольотів Державної прикордонної служби України, спеціальних засобів та заходів фізичного впливу під час охорони державного кордону та виключної (морської) економічної зони України : Наказ Адміністрації Державної прикордонної служби України від 21 жовтня 2003 р. № 200 / Державна прикордонна служба України. Офіиійний вісник України. 2003. № 43. С. 172.

12. Організація соціальних систем обігу зброї : монографія / А. Корнієць, О. Фролов ; за ред. В. Пєткова. Київ, 2008. 182 с.

13. Довідка щодо вивчення та узагальнення практики застосування адміністративними судами законодавства під час розгляду та вирішення впродовж 2010-2011 років справ стосовно реалізації права на мирні зібрання (збори, мітинги, походи, демонстрації тощо) від 1 квітня 2012 р. / Вищий адміністративний суд України. URL: https://zakon.rada.gov.ua/ laws/show/n0002760-12. 
14. Case of Stankov and the United Macedonian Organization Ilinden v. Bulgaria from 2 October 2001, case № 29221/95 / European Court of Human Rights. URL: https://hudoc.echr.coe.int/ eng\#\{\%22fulltext $\% 22:[\% 22$ stankov $\% 22], \% 22$ documentcollectionid $\% 22:[\% 22$ GRANDCHAMBER\%22,\%22CHAMBER\%22],\%22itemid\%22:[\%22001-59689\%22]\}.

15. Case of Cisse v. France from 9 April 2002, case № 51346/99 / European Court of Human Rights. URL: https://hudoc.echr.coe.int/eng\#\{\%22fulltext $\% 22:[\% 2251346 \% 22], \% 22$ documentcollectionid2\%22:[\%22GRANDCHAMBER\%22,\%22CHAMBER\%22],\%22ite $\operatorname{mid} \% 22:[\% 22001-60413 \% 22]\}$.

16. Case of Christian Democratic People’s Party v. Moldova (№ 2) from 2 February 2010, case № 25196/04 / European Court of Human Rights. URL: https://hudoc.echr.coe.int/eng\# \{\%22fulltext $\% 22:[\% 2225196 \% 22], \% 22$ documentcollectionid2\%22:[\%22GRANDCHAMBER $\% 22, \%$ 22CHAMBER\%22],\%22itemid\%22:[\%22001-97049\%22]\}.

17. Case of Galstyan v. Armenia from 15 November 2007, case № 26986/03 / European Court of Human Rights. URL: https://hudoc.echr.coe.int/eng\#\{\%22fulltext\%22:[\%22Galstyan\%22],\%22documentcollectionid2\%22:[\%22GRANDCHAMBER\%22,\%22CHAMBER\%22],\%22itemid\%22:[\%22001-83297\%22]\}.

18. Case of Jersild v. Denmark from 23 September 1994, case № 15890/89 / European Court of Human Rights. URL: https://hudoc.echr.coe.int/eng\#\{\%22fulltext\%22:[\%22jersild\%22],\%22documentcollectionid2\%22:[\%22GRANDCHAMBER \%22,\%22CHAMBER\%22] ,\%22itemid\%22:[\%22001-57891\%22]\}.

19. Case of Plattform “Ärzte für das Leben” v. Austria from 21 June 1988, case № 10126/82 / European Court of Human Rights. URL: https://hudoc.echr.coe.int/eng\#\{\%22fulltext $\% 22:[\% 22$ plattform $\% 22$ ], \%22documentcollectionid2\%22:[\%22GRANDCHAMBER\%22,\%22CHAMBER\%22],\%22itemid\%22:[\%22001-57558\%22]\}.

20. Case of Christian Against Racism and Fascism v. the United Kingdom from 16 July 1980, case № 8440/78 / European Court of Human Rights. URL: https://hudoc.echr.coe.int/eng\#\{\%22i temid $\% 22:[\% 22001-74287 \% 22]\}$.

21. Case of Alekseyev v. Russia from 21 October 2010, case № 4916/07 / European Court of Human Rights. URL: https://hudoc.echr.coe.int/eng\# \{\%22fulltext $\% 22:[\% 224916 \% 22], \% 22$ documentcollectionid2\%22:[\%22GRANDCHAMBER\%22,\%22CHAMBER\%22],\%22ite $\operatorname{mid} \% 22:[\% 22001-101257 \% 22]\}$.

22. Case of Artico v. Italy from 13 May 1980, case № 6694/74 / European Court of Human Rights. URL: https://hudoc.echr.coe.int/eng\#\{\%22tabview\%22:[\%22document $\% 22], \% 22$ ite mid\%22:[\%22001-57424\%22]\}.

23. Case of Oya Ataman v. Turkey from 5 December 2006, case № 74552/01 / European Court of Human Rights. URL: https://hudoc.echr.coe.int/eng\# $\{\% 22$ fulltext $\% 22:[\% 2274552 \% 22], \% 22$ documentcollectionid2\%22:[\%22GRANDCHAMBER \%22,\%22CHAMBER\%22],\%22ite $\operatorname{mid} \% 22:[\% 22001-78330 \% 22]\}$.

24. Case of Djavit An v. Turkey from 20 February 2003, case № 20652/92 / European Court of Human Rights. URL: https://hudoc.echr.coe.int/eng\#\{\%22fulltext\%22:[\%22djavit\%22],\%22documentcollectionid2\%22:[\%22GRANDCHAMBER\%22,\%22CHAMBER\%22],\%22ite mid\%22:[\%22001-60953\%22]\}.

25. Case of Makhmudov v. Russia from 26 July 2007, case № 35082/04 / European Court of Human Rights. URL: https://hudoc.echr.coe.int/eng\# $\{\% 22$ fulltext $\% 22:[\% 2235082 \% 22], \% 22$ documentcollectionid2\%22:[\%22GRANDCHAMBER\%22,\%22CHAMBER\%22],\%22ite $\operatorname{mid} \% 22:[\% 22001-81966 \% 22]\}$.

26. Case of Sergey Kuznetsov v. Russia from 23 October 2008, case № 10877/04 / European Court of Human Rights. URL: https://hudoc.echr.coe.int/eng\#\{\%22full- 


\section{НАУКОВИЙ АНАЛІЗ СУДОВОЇ ПРАКТИКИ}

text\%22:[\%2210877\%22],\%22documentcollectionid2\%22:[\%22GRANDCHAMBER\%22,\%22CHAMBER\%22],\%22itemid\%22:[\%22001-89066\%22]\}.

27. Case of United Communist Party of Turkey and others v. Turkey from 30 January 1998, case № 133/1996/752/951 / European Court of Human Rights. URL: https://hudoc.echr.coe.int/ eng\# $\{\% 22$ fulltext $\% 22:[\% 22$ communist $\% 22], \% 22$ documentcollectionid $2 \% 22:[\% 22$ GRANDCHAMBER\%22,\%22CHAMBER\%22],\%22itemid\%22:[\%22001-58128\%22]\}.

28. Case of Christian Democratic People's Party v. Moldova from 14 February 2006, case № 28793/02 / European Court of Human Rights. URL: https://hudoc.echr.coe.int/eng\# \{\%22fulltext\%22:[\%2228793\%22],\%22documentcollectionid2\%22:[\%22GRANDCHAMBER\%22,\%22CHAMBER\%22],\%22itemid\%22:[\%22001-72346\%22]\}.

29. Case of Incal v. Turkey from 9 June 1998, case № 41/1997/825/1031 / European Court of Human Rights. URL: https://hudoc.echr.coe.int/eng\# $\{\% 22$ fulltext $\% 22:[\% 22$ incal $\% 22], \% 22$ documentcollectionid2\%22:[\%22GRANDCHAMBER\%22,\%22CHAMBER\%22],\%22ite mid\%22:[\%22001-58197\%22]\}.

30. Case of Sürek v. Turkey (№ 1) from 8 July 1999, case № 26682/95 / European Court of Human Rights. URL: https://hudoc.echr.coe.int/eng\#\{\%22fulltext $\% 22:[\% 22 \mathrm{~S} \% \mathrm{C} 3 \% \mathrm{~B}-$ Crek\%22],\%22documentcollectionid2\%22:[\%22GRANDCHAMBER \%22,\%22CHAMBER\%2 2], $\% 22$ itemid $\% 22:[\% 22001-58279 \% 22]\}$.

31. Case of Ouranio Toxo and others v. Greece from 20 October 2005, case № 74989/01 / European Court of Human Rights. URL: https://hudoc.echr.coe.int/eng\#\{\%22fulltext $\% 22:[\% 22$ Ouranio $\% 20$ Toxo $\% 22], \% 22$ documentcollectionid $\% 22:[\% 22$ GRANDCHAMBER\%22,\%22CHAMBER\%22],\%22itemid\%22:[\%22001-70720\%22]\}.

32. Case of Barankevich v. Russia from 26 July 2007, case № 10519/03 / European Court of Human Rights. URL: https://hudoc.echr.coe.int/eng\#\{\%22fulltext $\% 22:[\% 2210519 \% 22], \% 22$ documentcollectionid2\%22:[\%22GRANDCHAMBER\%22,\%22CHAMBER\%22],\%22ite mid\%22:[\%22001-81950\%22]\}.

\section{References:}

1. Verkhovna Rada of Ukraine (2006). Pro vykonannia rishen ta zastosuvannia praktyky Yevropeiskoho sudu z prav liudyny: Zakon Ukrainy vid 23 liutoho 2006 r. № 3477-IV [On enforcement of decisions and application of the European Court of Human Rights practice: Law of Ukraine dated February 23, 2006 № 3477-IV]. Ofitsiinyi visnyk Ukrainy, no. 12, p. 16 [in Ukrainian].

2. Verkhovna Rada of Ukraine (1997). Pro ratyfikatsiiu Konventsii pro zakhyst prav liudyny i osnovopolozhnykh svobod 1950 roku, Pershoho protokolu ta Protokoliv № 2, 4, 7 ta 11 do Konventsii: Zakon Ukrainy vid 17 lypnia 1997 r. № 475/97-BP [On Ratification of the 1950 Convention on the Protection of Human Rights and Fundamental Freedoms, First Protocol and Protocols № 2, 4, 7 and 11 to the Convention: Law of Ukraine of July 17, 1997 № 475/97-BP]. Ofitsiinyi visnyk Ukrainy, no. 29, p. 11 [in Ukrainian].

3. Verkhovna Rada of Ukraine (2016). Konstytutsiia Ukrainy: Zakon Ukrainy vid 28 chervnia 1996 r. № 254к/96-BP (stanom na 1 veresnia 2016 r.) [The Constitution of Ukraine: Law of Ukraine dated June 28, 1996 № 254к/96-BP (as of September 1, 2016)]. Kharkiv: Pravo [in Ukrainian].

4. European Court of Human Rights (2013). Sprava "Vierentsov proty Ukrainy": rishennia Yevropeiskoho sudu z prav liudyny vid 11 kvitnia 2013 r. (zaiava № 20372/11) [Case "Vierenzov v. Ukraine": judgment of the European Court of Human Rights dated April 11, 2013 (application № 20372/11)]. Retrieved from: https://zakon.rada.gov.ua/laws/ show/974_945 [in Ukrainian]. 
5. Verkhovna Rada of Ukraine (2005). Kodeks administratyvnoho sudochynstva Ukrainy: Zakon Ukrainy vid 6 lypnia 2005 r. № 2747-IV [Code of Administrative Justice of Ukraine: Law of Ukraine dated July 6, 2005 № 2747-IV]. Ofitsiinyi visnyk Ukrainy, no. 32, p. 11 [in Ukrainian].

6. Kuibida, R., Sereda, M., Trubenkova, O. (2018). Svoboda myrnykh zibran v Ukraini: poshuk optymalnoi modeli rehuliuvannia [Freedom of Peaceful Assembly in Ukraine: Search for an Optimal Model of Regulation]. Center for Political and Legal Reforms, Democracy Reporting International. Retrieved from: http://pravo.org.ua/img/zstored/files/myrni_zibrannia_v_Ukraini. pdf [in Ukrainian].

7. Melnyk, R. (2015). Pravo na svobodu myrnykh zibran: teoriia i praktyka: monohrafiia [The right to freedom of peaceful assembly: theory and practice: a monograph]. Kyiv: VAITE [in Ukrainian].

8. Shkarneha, O. (2016). Provadzhennia u spravakh shchodo realizatsii prava na myrni zibrannia [Proceedings in the realm of the right to peaceful assembly] (Extended abstract of candidate's thesis). Odesa [in Ukrainian].

9. Constitutional Court of Ukraine (2016). Rishennia Konstytutsiinoho Sudu Ukrainy u spravi za konstytutsiinym podanniam Upovnovazhenoho Verkhovnoi Rady Ukrainy z prav liudyny shchodo vidpovidnosti Konstytutsii Ukrainy (konstytutsiinosti) polozhen chastyny p'iatoi statti 21 Zakonu Ukrainy «Pro svobodu sovisti ta relihiini orhanizatsii» (sprava pro zavchasne spovishchennia pro provedennia publichnykh bohosluzhin, relihiinykh obriadiv, tseremonii ta protsesii) vid 8 veresnia 2016 r. № 6-pп/2016 [The decision of the Constitutional Court of Ukraine in the case of the constitutional petition of the Ukrainian Parliament Commissioner for Human Rights on the compliance of the Constitution of Ukraine (constitutionality) with the provisions of part five of Article 21 of the Law of Ukraine "On Freedom of Conscience and Religious Organizations" (the case of an early notification of the conduct of public worship, religious ceremonies, ceremonies and processions) of September 8, 2016 № 6-pп/2016]. Ofitsiinyi visnyk Ukrainy, no. 79, p. 94 [in Ukrainian].

10. Dörr, O., Grote, R., Marauhn, T. (2013). EMRK/GG: Konkordanzkommentar zum europäischen und deutschen Grundrechtsschutz. 2. Auflage. Band 1. Kapitel 1-19 [ECHR/GG: Concordance Commentary on European and German Fundamental Rights Protection. $2^{\text {nd }}$ ed. Volume 1. Chapters 1-19]. Tübingen [in German].

11. State Border Guard Service of Ukraine (2003). Pro zatverdzhennia Instruktsii pro zastosuvannia zbroi, boiovoi tekhniky, ozbroiennia, korabliv (kateriv), litakiv i vertolotiv Derzhavnoi prykordonnoi sluzhby Ukrainy, spetsialnykh zasobiv ta zakhodiv fizychnoho vplyvu pid chas okhorony derzhavnoho kordonu ta vykliuchnoi (morskoi) ekonomichnoi zony Ukrainy: Nakaz Administratsii Derzhavnoi prykordonnoi sluzhby Ukrainy vid 21 zhovtnia 2003 r. № 200 [On approval of the Instruction on the use of weapons, military equipment, armaments, ships (boats), aircraft and helicopters of the State Border Guard Service of Ukraine, special means and measures of physical influence during the protection of the state border and the exclusive (maritime) economic zone of Ukraine: the order of the Administration of the State Border Guard Service Ukraine dated October 21, 2003 № 200]. Ofitsiinyi visnyk Ukrainy, no. 43, p. 172 [in Ukrainian].

12. Pietkov, V. (ed.) (2008). Orhanizatsiia sotsialnykh system obihu zbroi: monohrafiia [Organization of social systems for the circulation of weapons: a monograph]. Kyiv [in Ukrainian].

13. Supreme Administrative Court of Ukraine (2012). Dovidka shchodo vyvchennia ta uzahalnennia praktyky zastosuvannia administratyvnymy sudamy zakonodavstva pid chas rozghliadu ta vyrishennia vprodovzh 2010-2011 rokiv sprav stosovno realizatsii prava na myrni zibrannia (zbory, mitynhy, pokhody, demonstratsii toshcho) vid 1 kvitnia 2012 r. [Reference on the study and generalization of the practice of the application by administrative courts of legislation during the consideration and resolution of cases of 2010-2011 on the exercise of the right to peace- 


\section{НАУКОВИЙ АНАЛІЗ СУДОВОЇ ПРАКТИКИ}

ful assembly (meetings, rallies, campaigns, demonstrations, etc.) from April 1, 2012]. Retrieved from: https://zakon.rada.gov.ua/laws/show/n0002760-12 [in Ukrainian].

14. European Court of Human Rights (2001). Case of Stankov and the United Macedonian Organization Ilinden v. Bulgaria from 2 October 2001, case № 29221/95. Retrieved from: https://hudoc.echr. coe.int/eng\#\{\%22fulltext $\% 22:[\% 22$ stankov\%22],\%22documentcollectionid $2 \% 22:[\% 22$ GRANDCHAMBER\%22,\%22CHAMBER\%22],\%22itemid\%22:[\%22001-59689\%22]\} [in English].

15. European Court of Human Rights (2002). Case of Cisse v. France from 9 April 2002, case № 51346/99. Retrieved from: https://hudoc.echr.coe.int/eng\#\{\%22fulltex$\mathrm{t} \% 22:[\% 2251346 \% 22], \% 22$ documentcollectionid2\%22:[\%22GRANDCHAMBER \%22,\%22CHAMBER\%22],\%22itemid\%22:[\%22001-60413\%22]\} [in English].

16. European Court of Human Rights (2010a). Case of Christian Democratic People's Party v. Moldova (№ 2) from 2 February 2010, case № 25196/04. Retrieved from: https://hudoc.echr.coe.int/ eng\#\{\%22fulltext $\% 22:[\% 2225196 \% 22], \% 22$ documentcollectionid2\%22:[\%22GRANDCHAMBER\%22,\%22CHAMBER\%22],\%22itemid\%22:[\%22001-97049\%22]\} [in English].

17. European Court of Human Rights (2007a). Case of Galstyan v. Armenia from 15 November 2007, case № 26986/03. Retrieved from: https://hudoc.echr.coe.int/eng\#\{\%22fulltex$\mathrm{t} \% 22:[\% 22$ Galstyan $\% 22], \% 22$ documentcollectionid2\%22:[\%22GRANDCHAMBER \%22,\%22CHAMBER\%22],\%22itemid\%22:[\%22001-83297\%22]\} [in English].

18. European Court of Human Rights (1994). Case of Jersild v. Denmark from 23 September 1994, case № 15890/89. Retrieved from: https://hudoc.echr.coe.int/eng\#\{\%22fulltext\%22:[\%22jersild $\% 22$ ], $\% 22$ documentcollectionid2\%22:[\%22GRANDCHAMBER $\% 22, \% 22$ CHAMBER \%22],\%22itemid\%22:[\%22001-57891\%22]\} [in English].

19. European Court of Human Rights (1988). Case of Plattform “Ärzte für das Leben” v. Austria from 21 June 1988, case № 10126/82. Retrieved from: https://hudoc.echr.coe.int/eng\#\{\%22 fulltext $\% 22:[\% 22$ plattform $\% 22], \% 22$ documentcollectionid $\% 22:[\% 22$ GRANDCHAMBER\%22,\%22CHAMBER\%22],\%22itemid\%22:[\%22001-57558\%22]\} [in English].

20. European Court of Human Rights (1980a). Case of Christian Against Racism and Fascism v. the United Kingdom from 16 July 1980, case № 8440/78. Retrieved from: https://hudoc.echr. coe.int/eng\#\{\%22itemid\%22:[\%22001-74287\%22]\} [in English].

21. European Court of Human Rights (2010b). Case of Alekseyev v. Russia from 21 October 2010, case № 4916/07. Retrieved from: https://hudoc.echr.coe.int/eng\#\{\%22fulltext $\% 22:[\% 224916 \% 22], \% 22$ documentcollectionid2\%22:[\%22GRANDCHAMBER \%22,\%22CHAMBER\%22],\%22itemid\%22:[\%22001-101257\%22]\} [in English].

22. European Court of Human Rights (1980b). Case of Artico v. Italy from 13 May 1980, case № 6694/74. Retrieved from: https://hudoc.echr.coe.int/eng\#\{\%22tabview\%22:[\%22document $\% 2$ 2],\%22itemid\%22:[\%22001-57424\%22]\} [in English].

23. European Court of Human Rights (2006a). Case of Oya Ataman v. Turkey from 5 December 2006, case № 74552/01. Retrieved from: https://hudoc.echr.coe.int/eng\#\{\%22fulltext $\% 22:[\% 2274552 \% 22], \% 22$ documentcollectionid2\%22:[\%22GRANDCHAMBER \%22,\%22CHAMBER\%22],\%22itemid\%22:[\%22001-78330\%22]\} [in English].

24. European Court of Human Rights (2003). Case of Djavit An v. Turkey from 20 February 2003, case № 20652/92. Retrieved from: https://hudoc.echr.coe.int/eng\# \{\%22fulltext $\% 22:[\% 22 \mathrm{~d}-$ javit $\% 22], \% 22$ documentcollectionid2\%22:[\%22GRANDCHAMBER $\% 22, \% 22$ CHAMBER $\% 22$ ],\%22itemid\%22:[\%22001-60953\%22]\} [in English].

25. European Court of Human Rights (2007b). Case of Makhmudov v. Russia from 26 July 2007, case № 35082/04. Retrieved from: https://hudoc.echr.coe.int/eng\#\{\%22fulltex$\mathrm{t} \% 22:[\% 2235082 \% 22], \% 22$ documentcollectionid2\%22:[\%22GRANDCHAMBER \%22,\%22CHAMBER\%22],\%22itemid\%22:[\%22001-81966\%22]\} [in English]. 
26. European Court of Human Rights (2008). Case of Sergey Kuznetsov v. Russia from 23 October 2008, case № 10877/04. Retrieved from: https://hudoc.echr.coe.int/eng\#\{\%22fulltext $\% 22:[\% 2210877 \% 22], \% 22$ documentcollectionid2\%22:[\%22GRANDCHAMBER \%22,\%22CHAMBER\%22],\%22itemid\%22:[\%22001-89066\%22]\} [in English].

27. European Court of Human Rights (1998a). Case of United Communist Party of Turkey and others v. Turkey from 30 January 1998, case № 133/1996/752/951. Retrieved from: https://hudoc.echr.coe.int/eng\#\{\%22fulltext $\% 22$ :[\%22communist $\% 22], \% 22$ document collectionid2\%22:[\%22GRANDCHAMBER\%22,\%22CHAMBER\%22],\%22ite mid\%22:[\%22001-58128\%22]\} [in English].

28. European Court of Human Rights (2006b). Case of Christian Democratic People's Party v. Moldova from 14 February 2006, case № 28793/02. Retrieved from: https://hudoc.echr.coe.int/ eng\#\{\%22fulltext\%22:[\%2228793\%22],\%22documentcollectionid2\%22:[\%22GRANDCHAMBER\%22,\%22CHAMBER\%22],\%22itemid\%22:[\%22001-72346\%22]\} [in English].

29. European Court of Human Rights (1998b). Case of Incal v. Turkey from 9 June 1998, case № 41/1997/825/1031. Retrieved from: https://hudoc.echr.coe.int/eng\#\{\%22fulltext $\% 22:[\% 22$ incal\%22],\%22documentcollectionid2\%22:[\%22GRANDCHAMBER\%22,\%22CHAMBER\%22], \%22itemid\%22:[\%22001-58197\%22]\} [in English].

30. European Court of Human Rights (1999). Case of Sürek v. Turkey (№ 1) from 8 July 1999, case № 26682/95. Retrieved from: https://hudoc.echr.coe.int/eng\#\{\%22fulltext $\% 22:[\% 22 \mathrm{~S} \% \mathrm{C} 3 \%$ BCrek\%22],\%22documentcollectionid2\%22:[\%22GRANDCHAMBER\%22,\%22CHAMBER\%22],\%22itemid\%22:[\%22001-58279\%22]\} [in English].

31. European Court of Human Rights (2005). Case of Ouranio Toxo and others v. Greece from 20 October 2005, case № 74989/01. Retrieved from: https://hudoc.echr.coe.int/eng\#\{\%22fulltext $\% 22:[\% 22$ Ouranio $\% 20$ Toxo $\% 22], \% 22$ documentcollectionid2\%22:[\%22GRANDCHAMBER\%22,\%22CHAMBER\%22],\%22itemid\%22:[\%22001-70720\%22]\} [in English].

32. European Court of Human Rights $(2007 \mathrm{c})$. Case of Barankevich v. Russia from 26 July 2007, case № 10519/03. Retrieved from: https://hudoc.echr.coe.int/eng\#\{\%22fulltext\%22:[\%2210519\%22],\%22documentcollectionid2\%22:[\%22GRANDCHAMBER\%22,\%22CHAMBER\%22],\%22itemid\%22:[\%22001-81950\%22]\} [in English].

\title{
ДЕЯКІ АСПЕКТИ РОЗУМІННЯ КАТЕГОРІЇ «МИРНІСТЬ» У ПРАКТИЦІ ЄВРОПЕЙСЬКОГО СУДУ $З$ ПРАВ ЛЮДИНИ ЯК УМОВА ДОТРИМАННЯ ПРАВА НА СВОБОДУ МИРНИХ ЗІБРАНЬ
}

\author{
Катерина Солодова, \\ аспірант Геттінгенського університету імені Георга-Августа (Геттінген, Німеччина) \\ https://orcid.org/0000-0001-9878-2802 \\ solodova_kateryna@ukr.net
}

Статтю присвячено аналізу національних і міжнародних умов реалізації права на свободу мирних зібрань, серед яких чільне місце посідає категорія «мирність». Конвенція про захист прав людини і основоположсних свобод, як і Конституція України, одноголосно зазначають, шуо громадяни мають право збиратися лише мирно. Це формулювання визначає мету статті, для досягнення якої автор більш детально розглядає зміст категорії «мирність», щуо є необхідною умовою реалізачії права на свободу мирних зібрань. Для досягнення поставленої мети автором використовуються методи та прийоми логіки, сходження від загального до конкретного, зокрема, аналізується 


\section{НАУКОВИЙ АНАЛІЗ СУДОВОЇ ПРАКТИКИ}

практика Європейського суду з прав людини в справах щчодо реалізаиії громадянами права на свободу мирних зібрань, результатом чого є вироблення критерїв для визначення мирного характеру зібрання. Автор акиентує увагу на таких аспектах категорії «мирність», як відсутність зброї під час проведення зібрання або незастосування ії учасниками такого зібрання, відсутність мети й бажання застосування насильницьких намірів в організаторів та учасників зібрання, активні немирні дії контрдемонстрантів мирного зібрання, заклики йлозунги зібрання різного характеру (у тому числі державного чи політичного), щуо викликають невдоволення іншої частини населення, а також особливості очінки негативних дій окремих учасників масового зібрання.

Як висновок автором зазначається, що відсутність в українському законодавстві спечіального закону, який регулював би прочедурні аспекти здійснення громадянами права на свободузібрань, призводить до виникнення ситуачій, якімають свойм наслідком численні порушення також у вигляді необгрунтованої заборони реалізації громадянами наданого їм права. У зв'язку з наведеним автор пропонус активно застосовувати міжнародні джерела права, щчо мають важливі напраџювання в регулюванні иієї сфери. Одним із найбільш суттєвих джерел є практика Європейського суду з прав людини як невід'ємна частина реалізації норм Конвениії про захист прав людини і основоположних свобод. Суд надає суттєве тлумачення категорії «мирність» під час вирімення спорів, пов'язаних із порушенням права на свободу мирних зібрань. Ці напрацювання європейської судової установи повинні не лиме бути певним дороговказом для організаторів та учасників мирного зібрання, а й усебічно застосовуватися суб' єктами публічної адміністрації.

Ключові слова: мирний характер, ненасильницький характер, зброя, контрдемонстранти, лозунги, плакати, масове зібрання, публічне місце. 